\title{
PLANKTONIC COELENTERATES COLLECTED IN THE NORTH ATLANTIC OCEAN
}

\author{
by \\ R. W. M. VAN SOEST \\ Institute of Taxonomic Zoology, University of Amsterdam, The Netherlands
}

\begin{abstract}
This short faunistic note contains a report on the species of Scyphozoa, Hydromedusac, Siphonophora and Ctenophora that were collected by OWS "Cirrus" and "Cumulus", R.V. "Tridens" and HMS "Snellius" in the North Atlantic Ocean between $22^{\circ} \mathrm{N}$ and $66^{\circ} \mathrm{N}$. In all, 61 species have been captured. New records for Calycopsis typa Fewkes, 1882, Cunina duplicata Maas, 1893, Sibogita geometrica N.aas, 1905 ssp. occidentalis Kramp, 1959, Apolemia uvaria (Lesueur, 1811), Thalassophyes crystallina Moser, 1925 and Crystallophyes amygdalina Moser, 1925, are given.
\end{abstract}

\section{INTRODUCTION}

Although the north-eastern Atlantic Ocean is one of the most thoroughly investigated oceanic areas, the knowledge of the distribution of the oceanic plankton species, particularly the meso- and bathypelagic ones, is by no means complete. New species are still to be described and new records are frequently reported. It seems thus justified to publish a faunistic note on the coelenterates that were collected by Dutch government vessels during the years 1963-1972. Most of the material presented here was collected during the various cruises of the Ocean Weather Ships "Cirrus" and "Cumulus" at five more or less fixed stations: $\mathrm{M}\left(66^{\circ} \mathrm{N}, 01^{\circ} \mathrm{E}\right), \mathrm{A}\left(62^{\circ} \mathrm{N}, 33^{\circ} \mathrm{W}\right)$, I $\left(59^{\circ} \mathrm{N}\right.$, $\left.19^{\circ} \mathrm{W}\right), \mathrm{J}\left(52^{\circ} \mathrm{N}, 20^{\circ} \mathrm{W}\right)$ and $\mathrm{K}\left(45^{\circ} \mathrm{N}, 16^{\circ} \mathrm{W}\right)$. At these stations the ships were moving over an area the extent of which was at most one degree latitude and longitude. These "moving" stations were frequently sampled during the period of 1963-1972. Additional material was collected by HMS "Snellius" during 1964/1965 in the area between the west coast of Africa and Bermuda. Finally an important part of the material was collected by the Fisheries Investigation Vessel RV "Tridens" during a cruise to and from the Azores; this cruise was attended by the author. All stations from which samples were studied are mentioned in table I and fig. 1.

I am much indebted to Mr. C. L. Bekkering, Mr. S. D. Koning and Mr. H. A. J. Donkers of the "Cirrus" and" Cumulus" and to the commanding officer and the crew of HMS "Snellius" for supplying the plankton samples, and to captain A. Krijgsman and his crew of the "Tridens" for their skill and cooperation in obtaining the Azores-plankton. Dr. C. L. Deelder of the Rijksinstituut voor Visserijonderzoek (RIVO) at IJmuiden was very kind in providing me with the opportunity to join the "Tridens" cruise. Dr. P. Pugh (National Institute of Oceanography, Great Britain) kindly identified some species of physonect siphonophores.

For the identification of the species the studies of Kramp (1959), Totton (1954, 1965), Bigelow (1911), Sears (1953), Moser (1925), and Russell (1953, 1970) were used.

\section{RESULTS}

Tables II, III and IV contain a list of all species that were found in the plankton samples mentioned in table I. The stations (latitude only) at which they occurred are indicated by a cross. In this way tables II, III and IV give a latitudinal distribution pattern of the species as it appeared from the samples. This does not necessarily mean that the species do not occur outside the area indicated in the tables, as absence of a species from a sample does not prove that the species is absent in the area the sample is supposed to represent. In fact, many species of oceanic coelenterates seem to be quite rare judging from the number of records. 
Table I. List of oceanic stations from which samples were studied.

\begin{tabular}{|c|c|c|c|c|c|c|}
\hline Station & Position & Date & Time & & Depth & \\
\hline CIRRUS M & $\left.66^{\circ} \mathrm{N}, 01^{\circ} \mathrm{E}^{*}\right)$ & IX-1964 & - & Several & l deep & hauls \\
\hline " & $620 \mathrm{~N}$ & VII-1964 & - & " & " & " \\
\hline CIRRUS A & $\left.62^{\circ} \mathrm{N}, 33^{\circ} \mathrm{W}^{*}\right)$ & VIII-IX-1963 & 一 & $"$ & $"$ & $"$ \\
\hline$"$ & " & II/III-1964 & - & " & $"$ & $"$ \\
\hline " & $"$ & III-1965 & 一 & ", & $"$ & $"$ \\
\hline$"$ & $"$ & $X-1965$ & - & $"$ & $"$ & $"$ \\
\hline$"$ & $"$ & IV/V-1966 & - & $"$ & " & $"$ \\
\hline$"$ & " & VI/VII-1968 & 一 & $"$ & $"$ & $"$ \\
\hline " & $"$ & V-1972 & - & 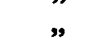 & $"$ & $"$ \\
\hline CIRRUS I & $\left.59^{\circ} \mathrm{N}, 19^{\circ} \mathrm{W}^{*}\right)$ & XI/XII-1963 & - & $"$ & $"$ & $"$ \\
\hline " & " & VI-1964 & 一 & $"$ & $"$ & $"$ \\
\hline " & $"$ & VIII-1965 & - & $"$ & $"$ & $"$ \\
\hline$"$ & $"$ & I-1966 & - & 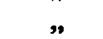 & $"$ & $"$ \\
\hline CIRRUS J & $\left.52^{\circ} \mathrm{N}, 20^{\circ} \mathrm{W}^{*}\right)$ & I-1964 & - & " & $"$ & $"$ \\
\hline$"$ & " & II-1966 & - & $"$ & $"$ & $"$ \\
\hline CIRRUS K & $\left.45^{\circ} \mathrm{N}, 16^{\circ} \mathrm{W}^{*}\right)$ & $X-1963$ & 一 & $"$ & $"$ & $"$ \\
\hline$"$ & $"$ & IV/V-1964 & 一 & $"$ & $"$ & $"$ \\
\hline " & $"$ & XI-1965 & 一 & $"$ & $"$ & $"$ \\
\hline " & " & V/VI-1966 & 一 & " & " & $"$ \\
\hline$"$ & ” & III/IV-1970 & 一 & $"$ & $"$ & $"$ \\
\hline$"$ & $"$ & $\mathrm{I}-1972$ & - & $"$ & $"$ & $"$ \\
\hline$"$ & $"$ & VI-1972 & - & $"$ & " & $"$ \\
\hline TRIDENS 4 & $43^{\circ} 30^{\prime} \mathrm{N}, 09^{\circ} 44^{\prime} \mathrm{W}$ & $30-V-1972$ & $08.30-11.00$ & & $350-0 \mathrm{~m}$ & \\
\hline TRIDENS 5 & $42^{\circ} 23^{\prime} \mathrm{N}, 12^{\circ} 38^{\prime} \mathrm{W}$ & $30 / 31-V-1972$ & $22.15-00.20$ & & $150-0 \mathrm{~m}$ & \\
\hline TRIDENS 7 & $39^{\circ} 15^{\prime} \mathrm{N}, 21^{\circ} 25^{\prime} \mathrm{W}$ & 1-VI-1972 & $13.30-16.30$ & & $700-0 \mathrm{~m}$ & \\
\hline TRIDENS 8 & $38^{\circ} 58^{\prime} \mathrm{N}, 22^{\circ} 37^{\prime} \mathrm{W}$ & 1-VI-1972 & $22.00-24.00$ & & $150-0 \mathrm{~m}$ & \\
\hline TRIDENS 9 & $39^{\circ} 26^{\prime} \mathrm{N}, 23^{\circ} 22^{\prime} \mathrm{W}$ & 6-VI-1972 & $21.00-24.00$ & & $150-0 \mathrm{~m}$ & \\
\hline TRIDENS 10 & $42^{\circ} 30^{\prime} \mathrm{N}, 19^{\circ} 30^{\prime} \mathrm{W}$ & 7-VI-1972 & $21.00-24.00$ & & $150-0 \mathrm{~m}$ & \\
\hline TRIDENS 11 & $46^{\circ} 25^{\prime} \mathrm{N}, 15^{\circ} 00^{\prime} \mathrm{W}$ & 8-VI-1972 & $21.00-24.00$ & & $150-0 \mathrm{~m}$ & \\
\hline TRIDENS 12 & $49^{\circ} 00^{\prime} \mathrm{N}, 11^{\circ} 27^{\prime} \mathrm{W}$ & 9.VI-1972 & $19.30-23.00$ & & $300-0 \mathrm{~m}$ & \\
\hline SNELLIUS J 3 & $36^{\circ} 44^{\prime} \mathrm{N}, 55^{\circ} 00^{\prime} \mathrm{W}$ & $17-V-1965$ & 21.00 & & - & \\
\hline NELLIUS J 4 & $37^{\circ} 26^{\prime} \mathrm{N}, 38^{\circ} 46^{\prime} \mathrm{W}$ & $20-V-1965$ & - & & - & \\
\hline SNELLIUS J 5 & $37^{\circ} 15^{\prime} \mathrm{N}, 27^{\circ} 40 \mathrm{~W}^{\prime}$ & $22-V-1965$ & - & 2400 & m wire & out \\
\hline NELLIUS J 5a & $37^{\circ} 15^{\prime} \mathrm{N}, 27^{\circ} 40 \mathrm{~W}^{\prime}$ & 23-V-1965 & 18.00 & & - & \\
\hline NELLIUS I 1 & $33^{\circ} 53^{\prime} \mathrm{N}, 12^{\circ} 55^{\prime} \mathrm{W}$ & 9-IV-1965 & 22.00 & & - & \\
\hline NELLIUS I 1a & $33^{\circ} 53^{\prime} \mathrm{N}, 12^{\circ} 55^{\prime} \mathrm{W}$ & 10-IV-1965 & 10.45 & & 一 & \\
\hline NELLIUS I 2 & $33^{\circ} 52^{\prime} \mathrm{N}, 19^{\circ} 20^{\prime} \mathrm{W}$ & 11-IV-1965 & 16.30 & & - & \\
\hline NELLIUS I $2 a$ & $33^{\circ} 52^{\prime} \mathrm{N}, 19^{\circ} 20^{\prime} \mathrm{W}$ & 12-IV-1965 & 07.00 & & $50-0 \mathrm{~m}$ & \\
\hline NELLIUS I 3 & $34^{\circ} 06^{\prime} \mathrm{N}, 30^{\circ} 08^{\prime} \mathrm{W}$ & 14-IV-1965 & 11.45 & & 一 & \\
\hline NELLIUS I 4 & $34^{\circ} 09^{\prime} \mathrm{N}, 39^{\circ} 03^{\prime} \mathrm{W}$ & 16-IV-1965 & 19.30 & & - & \\
\hline NELLIUS Navado F-1 & $25^{\circ} 12^{\prime} \mathrm{N}, 70^{\circ} 23^{\prime} \mathrm{W}$ & $16 \cdot I-1965$ & 21.45 & & $10 \mathrm{~m}$ & \\
\hline NELLIUS Navado F-7 & $25^{\circ} 11^{\prime} \mathrm{N}, 19^{\circ} 35^{\prime} \mathrm{W}$ & 31-I-1965 & 20.00 & & $110 \mathrm{~m}$ & \\
\hline NELLIUS Echo 5 & $22^{\circ} 01^{\prime} \mathrm{N}, 49^{\circ} 55^{\prime} \mathrm{W}$ & 13-XII-1964 & 18.50 & & $100 \mathrm{~m}$ & \\
\hline
\end{tabular}

*) Note: The "Cirrus" and "Cumulus" stations (both indicated as CIRRUS in this table) are "moving" stations. The above listed positions are approximated. Deviations of these listed positions are small, not exceeding one degree latitude or longitude.

Common or fairly common species in the area west of the British Isles are Aeginura grimaldi Maas, 1904, Aglantha digitale (O. F. Müller, 1776), Botrynema brucei Browne, 1908, Halicreas minimum Fewkes, 1882, Pantachogon haeckeli Maas, 1893, Atolla wyvillei Haeckel, 1880, Periphylla periphylla (Péron \& Lesueur, 1809), Lensia conoidea (Kefferstein \& Ehlers, 1860), Chu- niphyes multidentata Lens \& van Riemsdijk, 1908, and Beroe cucumis Fabricius, 1780. In the samples from north of $60^{\circ} \mathrm{N}$, Dimophyes arctica Chun, 1897 and Crossota rufobrunnea (Kramp, 1913), were common. South of $50^{\circ} \mathrm{N}$, Hippopodius hippopus (Forskål, 1776), Rosacea plicata Quoy \& Gaimard, 1827, Vogtia spinosa Kefferstein \& Ehlers, 1861, Chelophyes appendiculata (Eschscholtz, 


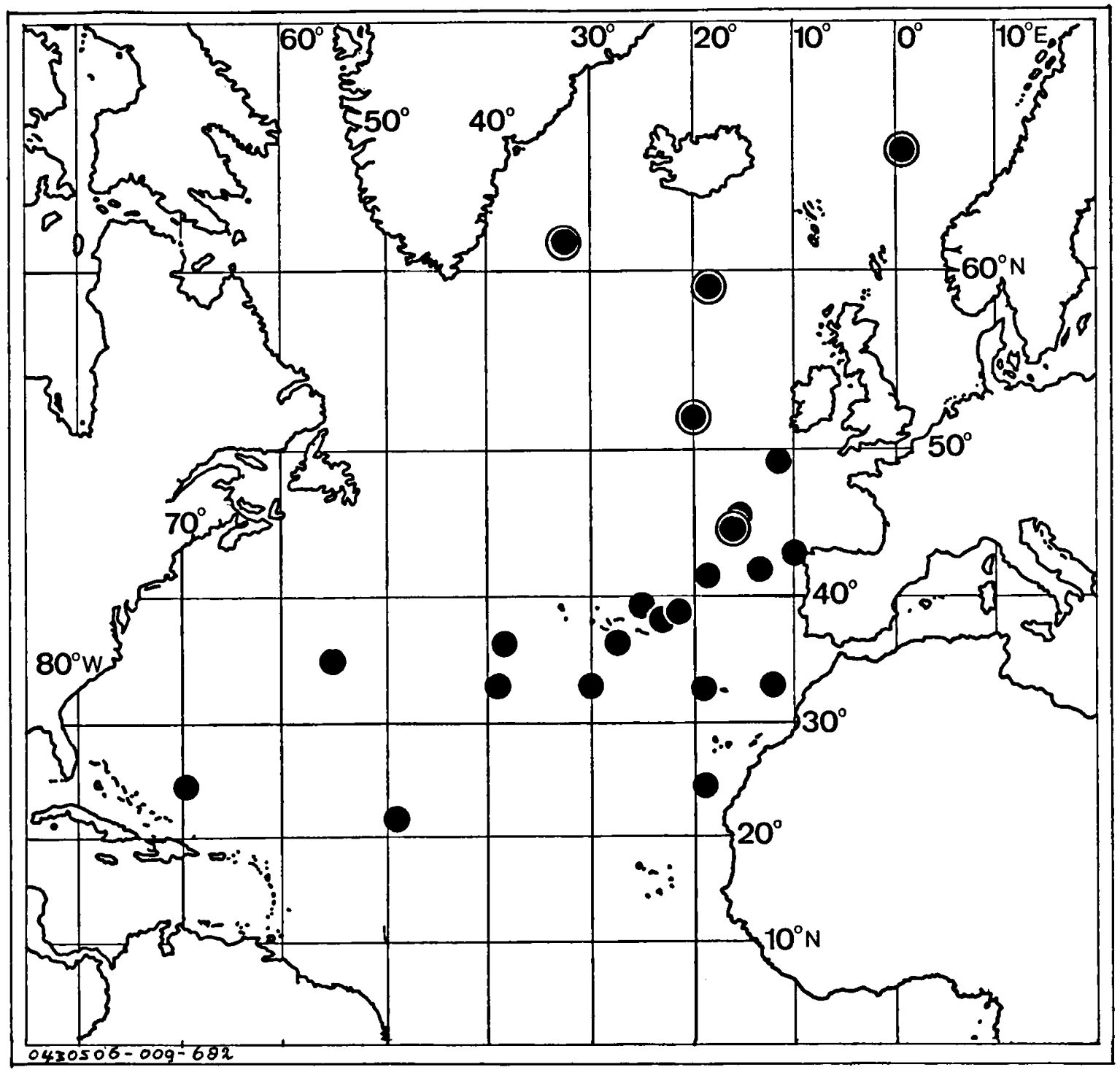

Fig. 1. Map of stations from which samples were studied. Circumlined dots are "moving" stations (see text).

1829), Eudoxoides spiralis (Bigelow, 1911) and Pelagia noctiluca (Forskål, 1775), were frequently met. South of $35^{\circ} \mathrm{N}$, Liriope tetraphylla (Chamisso \& Eyssenhardt, 1821), Aglaura hemistoma Péron \& Lesueur, 1809, Bassia bassensis (Quoy \& Gaimard, 1833) and Diphyes dispar Chamisso \& Eyssenhardt, 1821 were the dominating species.

\section{New or interesting records:}

Calycopsis typa Fewkes, 1882 (fig. 2A), has originally been described from waters over the continental shelf off the east coast of North America. Bigelow (e.g. 1922) collected specimens in the same area. Kramp (1959) found several specimens near the Cape Verde Islands. These are the only certain records of this species so far, although possibly some West Indian specimens found by Kramp (l.c.) could in his opinion also belong to this species. RV "Tridens" collected one specimen north-east of São Miguel (one of the Azores) (station 7: $39^{\circ} 15^{\prime} \mathrm{N}, 21^{\circ} 25^{\prime} \mathrm{W}$ ). This new record links the records of Fewkes (1882), Bigelow (l.c.) and Kramp (l.c.).

Cunina duplicata Maas, 1893. The northernmost 
Table II. List of species of siphonophores collected in the North Atlantic Ocean. The stations at which the species occurred (latitudinal position only) are indicated by crosses. For the exact positions of the stations see table $I$.

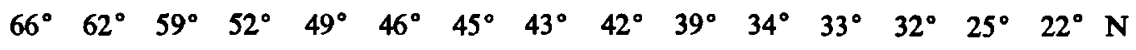

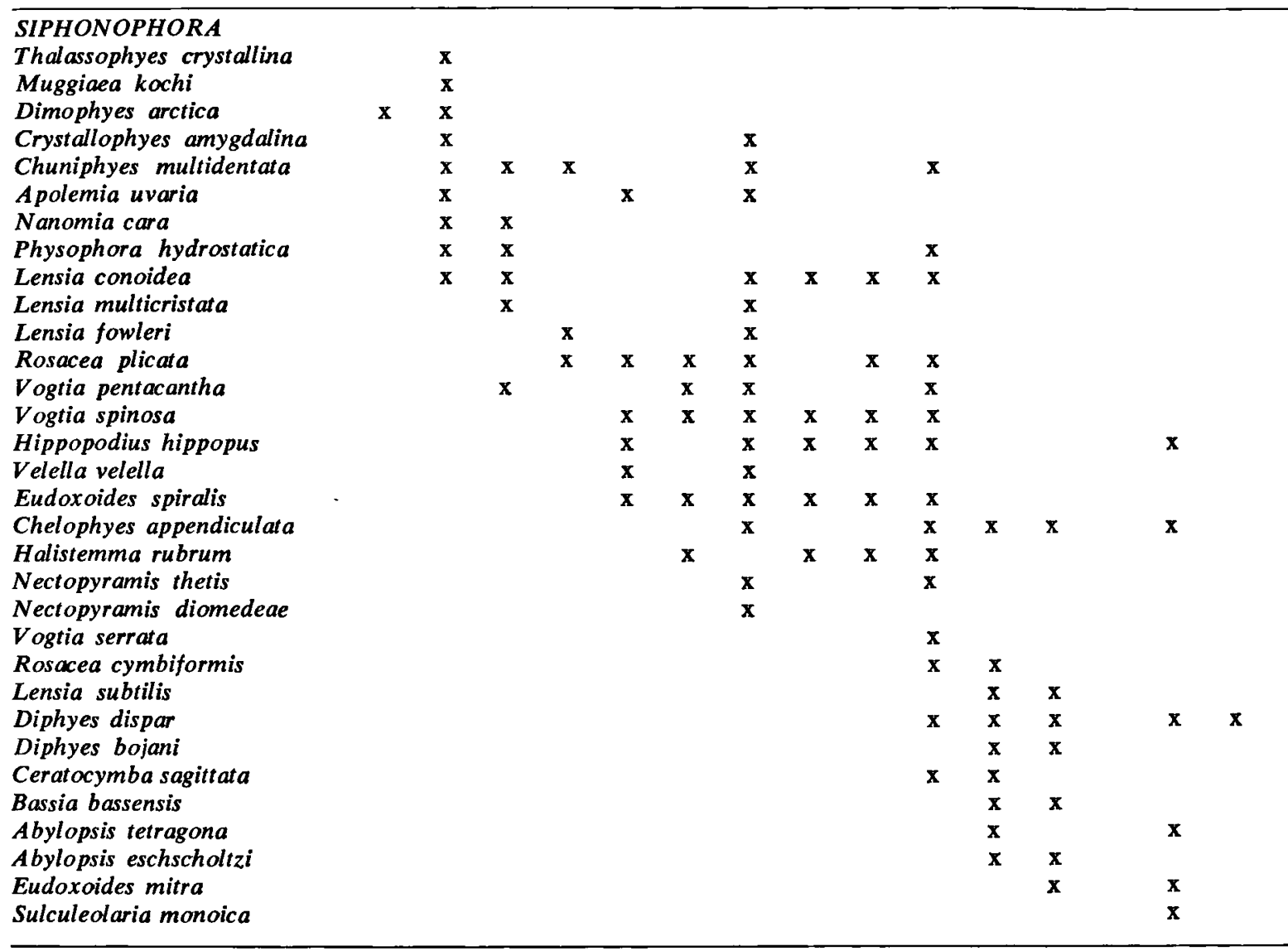

record of Kramp (1959) in the Atlantic Ocean is $37^{\circ} 25^{\prime} \mathrm{N}, 41^{\circ} 00^{\prime} \mathrm{W}$. The one rather damaged specimen collected by RV "Tridens" north east of São Miguel (39 $15^{\circ} \mathrm{N}, 21^{\circ} 25^{\prime} \mathrm{W}$ ) represents a slight northward extension of the known range of this species.

Pandea conica (Quoy \& Gaimard, 1827) (fig. 2B). One specimen was collected by RV "Tridens" at $38^{\circ} 58^{\prime} \mathrm{N}, 22^{\circ} 37^{\prime} \mathrm{W}$ (st. 8). It is an interesting specimen because it lacks the characteristic apical process, just as the specimen described by Bigelow (1918) from the Bermuda area. It has 32 marginal tentacles, which is in accordance with the number found in specimens off Bermuda (Bigelow, 1938). Its height is 20 $\mathrm{mm}$, its width $14 \mathrm{~mm}$, which makes it a fairly large specimen because of the absence of the apical projection. $P$. conica is common in the Mediterranean, but has been found in the Atlantic near Bermuda, along the west coast of Africa near Patagonia and in the Azores area (Kramp, 1959). It also occurs in the Pacific.

Sibogita geometrica Maas, 1905 ssp. occidentalis Kramp, 1959 (fig. 2C). This rare form has been found at three locations in the Atlantic Ocean by Kramp (1959): $36^{\circ} 41^{\prime} \mathrm{N}, 26^{\circ} 21^{\prime} \mathrm{W}$ (one specimen); $39^{\circ} 26^{\prime} \mathrm{N}, 21^{\circ} 51^{\prime} \mathrm{W}$ (one specimen); and $47^{\circ} 04^{\prime} \mathrm{N}, 07^{\circ} 08^{\prime} \mathrm{W}$ (one specimen). RV "Tridens" collected one specimen at station $9\left(39^{\circ} 26^{\prime} \mathrm{N}, 23^{\circ} 22^{\prime} \mathrm{W}\right)$, quite near one of the locations of Kramp (l.c.). Another specimen must be mentioned. It was not collected by one of the research vessels of which the material is at present reported upon, but taken by MS "Walther Herwig" near the equator (St. WH 471-II-71, $02^{\circ} 29^{\prime} \mathrm{S}, 18^{\circ} 58^{\prime} \mathrm{W}, 10-\mathrm{IV}-1971,19.50-20.50 \mathrm{~h}$, 300-304 m). This brings the total number of specimens known of this subspecies to five.

Neoturris pileata (Forskål, 1775) (fig. 2D). Two specimens were collected by RV "Tridens" at 
Table III. List of species of Hydromedusae collected in the North Atlantic Ocean. The stations at which the species occurred (latitudinal position only) are indicated by crosses. For the exact positions of the stations see table I.

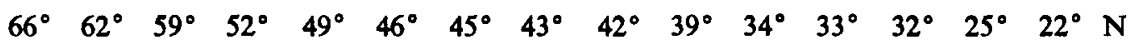

HYDROMEDUSAE

Crossota rufobrunnea

Botrynema brucei

Aglantha digitale

Aeginura grimaldi

Aeginura grimaldi

Tiaranna rotunda

Haliscera bigelowi

Pantachogon haeckeli

Neoturris pileata

Rhopalonema funerarium

Solmissus incisa (fragm.)

Colobonema sericeum

Aegina citrea

Calycopsis typa

Cunina duplicata

Pandea conica

Sibogita geometrica ssp. occidentalis

Rhopalonema velatum

Liriope tetraphylla

Cunina frugifera

Aglaura hemistoma

$\mathbf{x} \quad \mathbf{x}$

$\begin{array}{llll}\mathbf{x} & & & \\ \mathbf{x} & \mathbf{x} & \mathbf{x} & \\ \mathbf{x} & \mathbf{x} & \mathbf{x} & \mathbf{x} \\ \mathbf{x} & \mathbf{x} & & \\ & \mathbf{x} & & \\ \mathbf{x} & \mathbf{x} & \mathbf{x} & \\ \mathbf{x} & \mathbf{x} & \mathbf{x} & \\ \mathbf{x} & \mathbf{x} & \mathbf{x} & \end{array}$

$\begin{array}{cccc} & \mathbf{x} & & \\ & & & \\ & & \\ & & \\ \mathbf{x} & & & \\ \mathbf{x} & & & \mathbf{x} \\ \mathbf{x} & & \mathbf{x} & \mathbf{x} \\ & & & \mathbf{x} \\ & & & \mathbf{x} \\ & & & \mathbf{x} \\ & & & \mathbf{x}\end{array}$

Table IV. List of species of Scyphomedusae and Ctenophora collected in the North Atlantic Ocean. The stations at which the species occurred (latitudinal positions only) are indicated by crosses. For the exact positions of the stations, see table I.

\begin{tabular}{|c|c|c|c|c|c|c|c|c|c|c|c|c|c|c|c|}
\hline & $66^{\circ}$ & $62^{\circ}$ & $59^{\circ}$ & $52^{\circ}$ & $49^{\circ}$ & $46^{\circ}$ & $45^{\circ}$ & $43^{\circ}$ & $42^{\circ}$ & $39^{\circ}$ & $34^{\circ}$ & $33^{\circ}$ & $32^{\circ}$ & $25^{\circ}$ & $22^{\circ} \mathrm{N}$ \\
\hline \multicolumn{16}{|l|}{ SCYPHOMEDUSAE } \\
\hline Atolla wyvillei & $\mathbf{x}$ & $x$ & $\mathbf{x}$ & $\mathbf{x}$ & & & $\mathbf{x}$ & & & $\mathbf{x}$ & & & & & \\
\hline Periphylla periphylla & & $\mathbf{x}$ & $\mathbf{x}$ & $\mathbf{x}$ & $\mathbf{x}$ & $\mathbf{x}$ & & & & $\mathbf{x}$ & & & & & \\
\hline Nausithoe globifera & & $\mathbf{x}$ & & & & & $\mathbf{x}$ & & & & & & & & \\
\hline Atolla vanhoeffeni & & & & $\mathbf{x}$ & & & $x$ & & & & & & & & \\
\hline Atolla parva & & & & & & & $\mathbf{x}$ & & & $\mathbf{x}$ & & & & & \\
\hline Pelagia noctiluca & & & $\mathbf{x}$ & & & & $\mathbf{x}$ & & & $\mathbf{x}$ & & & & & \\
\hline \multicolumn{16}{|l|}{ CTENOPHORA } \\
\hline Beroe cucumis & & & $\mathbf{x}$ & & $\mathbf{x}$ & $\mathbf{x}$ & $\mathbf{x}$ & $\mathbf{x}$ & $\mathbf{x}$ & $\mathbf{x}$ & & & & & \\
\hline Hormiphora plumosa & & & & & & & & & & & $\mathbf{x}$ & & & $\mathbf{x}$ & \\
\hline
\end{tabular}

$43^{\circ} 30^{\prime} \mathrm{N}, 09^{\circ} 44^{\prime} \mathrm{W}$ ( st. 4). The number of marginal tentacles is 53 and 62 respectively for both specimens. The apical projection is weakly developed.

Apolemia uvaria (Lesueur, 1811) (Fig. 2G). Although considered as a Mediterranean siphonophore this species was found by Fraser (1961) in the northern North Sea and the Atlantic waters west of Scotland. RV "Tridens" collected several fine nectophores at $49^{\circ} 00^{\prime} \mathrm{N}, 11^{\circ} 27^{\prime} \mathrm{W}$ (st. 12). OWS "Cirrus" collected 2 nectophores at $45^{\circ} \mathrm{N}, 16^{\circ} \mathrm{W}$, and 1 nectophore at $62^{\circ} \mathrm{N}, 33^{\circ} \mathrm{W}$. The known range of this species is thus considerably extended. The fact that a specimen of this species was found at $62^{\circ} \mathrm{N}, 33^{\circ} \mathrm{W}$ in the month of March (1965) supports Fraser's (1967) assumption that the spocies may survive the boreal winter and is not a seasonal immigrant.

Thalassophyes crystallina Moser, 1925. One gonophore and one anterior nectophore of this species were collected by OWS "Cirrus" at $62^{\circ} \mathrm{N}$, $33^{\circ} \mathrm{W}$, thus confirming Fraser's (1961) records 


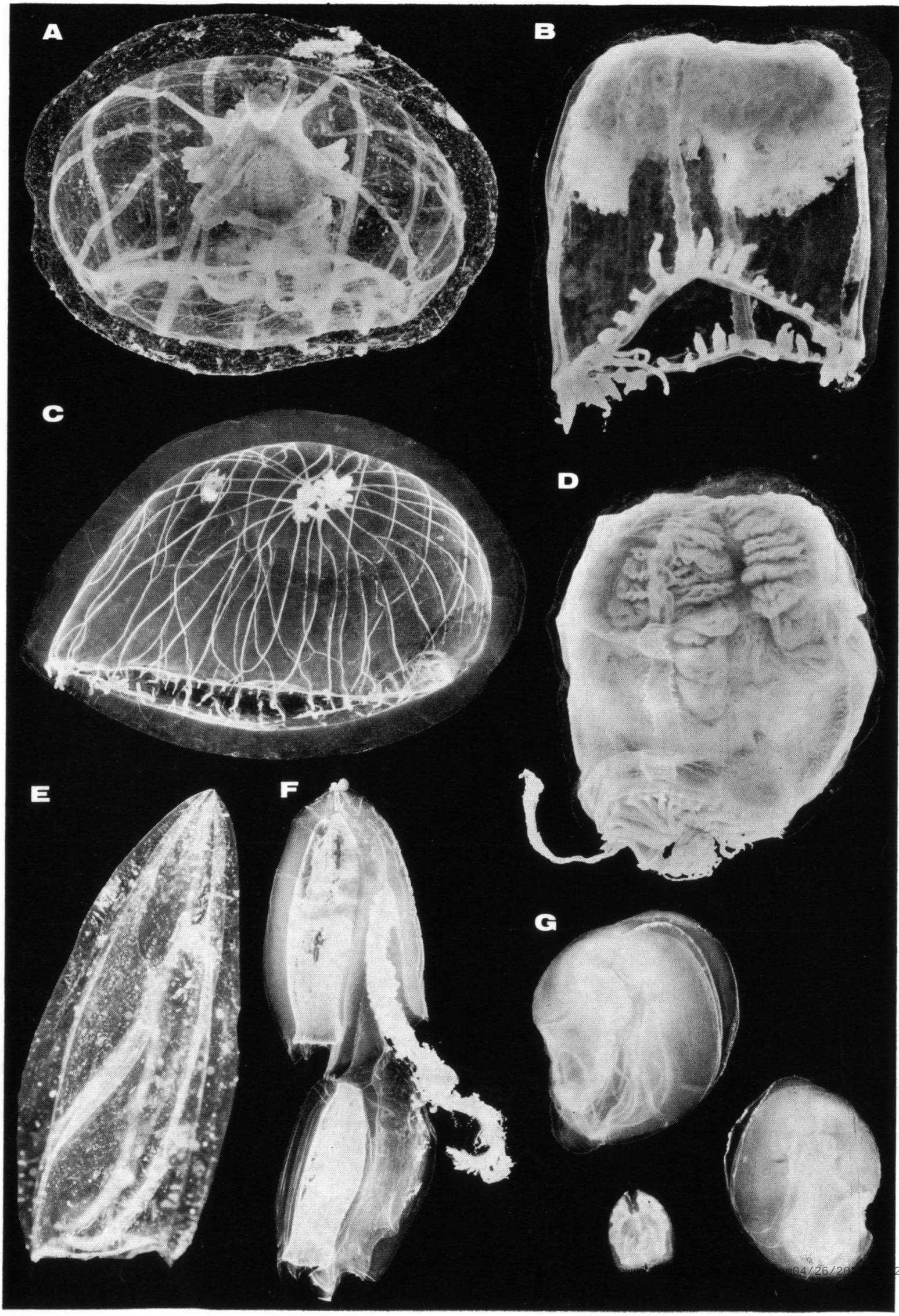


of occurrence of this species in the north-eastern Atlantic.

Crystallophyes amygdalina Moser, 1925 (fig. 2E). Several anterior and posterior nectophores belonging to this species were collected by OWS "Cirrus" at $62^{\circ} \mathrm{N}, 33^{\circ} \mathrm{W}$. One anterior nectophore was collected at $45^{\circ} \mathrm{N}, 16^{\circ} \mathrm{W}$. The species was hitherto only known from Antarctic waters and from the Subantartic Atlantic and Indian Ocean and from one location in the North Atlantic $\left(10^{\circ} \mathrm{N}\right)$ (Moser, 1925; Leloup, 1934; Totton, 1954). It is not the only species of siphonophore with a disrupt distribution in the North Atlantic as well as in the Southern Oceans (e.g. Muggiaea bargmannae Totton, 1954).

Diphyes dispar Chamisso \& Eyssenhardt, 1821 (fig. 2F). One gigantic specimen of this species collected by RV "Tridens" at st. $8\left(38^{\circ} 58^{\prime} \mathrm{N}\right.$, $\left.22^{\circ} 37^{\prime} \mathrm{W}\right)$ must be mentioned. Anterior and posterior nectophore of the polygastric phase each measure $40 \mathrm{~mm}$ in length, which makes it one of the biggest, if not the biggest specimen ever recorded of this well known and common species.

Dimophyes arctica (Chun, 1897). Quite a few specimens, both of the polygastric and the eudoxid phase, have been found in various samples taken by OWS "Cirrus" at $62^{\circ} \mathrm{N}, 33^{\circ} \mathrm{W}$ and $66^{\circ}$ N, $01^{\circ}$ E. Although Fraser $(1961,1967)$ considers it to be no longer an exclusively cold water form, since it has been found frequently in the central North Atlantic and even in tropical waters (e.g. Leloup, 1934; Alvarino, 1971), it was absent from all the samples studied at present except for the ones mentioned above.

\section{BIBLIOGRAPHY}

Alvarino, A., 1971. Siphonophores of the Pacific, with a review of the world distribution. Bull. Scripps Inst. Oceanogr., $16: 1-432$.

Bigelow, H. B., 1911. Report on the scientific results of the expedition to the Eastern Tropical Pacific, U.S. Fish Commission Steamer "Albatross", 23. The Siphonophorae. Mem. Mus. comp. Zool. Harv., 38 (2) : $171-401$.

,- 1918 . Some medusae and siphonophorae from the Western Atlantic. Bull. Mus. comp. Zool. Harv., 52 (8) : 365-442.

-, 1922. Exploration of the coastal waters off the northeastern United States in 1916 by the US Fisheries schooner "Grampus". Bull. Mus. comp. Zool. Harv., 65 : 85-188.

-, 1938. Plankton of the Bermuda Oceanographic Expeditions, 8. Medusae taken during the years 1929 and 1930. Zoologica, New York, 23 : 99-189.

FewkES, J. W., 1882. On the Acalephae of the east coast of New England. Bull. Mus. comp. Zool. Harv., 9 (8) : $291-310$.

Fraser, J. H., 1961. The oceanic and bathypelagic plankton of the north-east Atlantic. Mar. Res., 1961 (4) : $1-48$.
,- 1967. Siphonophora in the plankton to the North and West of the British Isles. Proc. roy. Soc. Edinburgh, (B) 70 (1) : 1-30.

KRAMP, P. L., 1959. The Hydromedusae of the Atlantic Ocean and adjacent waters. Dana Rep., 46 : 1-283.

LELOUP, E., 1934. Siphonophores calycophorides de l'Océan Atlantique tropical et austral. Bull. Mus. roy. Hist. nat. Belgique, 10 (6) : 1-64.

Moser, F., 1925. Die Siphonophoren der Deutschen Südpolar Expedition 1901-1903. Deutsch. Südpolarexp., 17 (Zool. 9) : 1-541.

Russell, F. S., 1953. The Medusae of the British Isles, 1: $1-530,35$ pls. (University Press, Cambridge).

- , 1970. The Medusae of the British Isles, 2 : 1-284, 15 pls. (University Press, Cambridge).

SeARS, M., 1953. Notes on Siphonophores 2. A revision of the Abylinae. Bull. Mus. comp. Zool. Harv., 109 (1) : $1-119$.

Totron, A. K., 1954. Siphonophora of the Indian Ocean. Discovery Rep., 27 : 1-162.

-, 1965. A synopsis of the Siphonophora: 1-230, 40 pls. (Trustees British Museum, London).

Received: 11 January 1973

Fig. 2. A. Calycopsis typa Fewkes, 1882 , from $39^{\circ} 15^{\prime} \mathrm{N}$, $21^{\circ} 25^{\prime} \mathrm{W}(\times 2.6)$.

B. Pandea conica (Quoy \& Gaimard, 1827) from $38^{\circ} 28^{\prime}$ $\mathrm{N}, 22^{\circ} 37^{\prime} \mathrm{W}(\times 3.0)$.

C. Sibogita geometrica Maas, 1905 ssp. occidentalis Kramp, 1959 , from $39^{\circ} 26^{\prime} \mathrm{N}, 21^{\circ} 51^{\prime} \mathrm{W}(\times 2.4)$.

D. Neoturris pileata (Forskål, 1775) from $43^{\circ} 30^{\prime} \mathrm{N}, 09^{\circ}$ $44^{\prime} \mathrm{W}(\times 2.4)$.
E. Crystallophyes amygdalina Moser, 1925, anterior nectophore from $45^{\circ} 00^{\prime} \mathrm{N}, 16^{\circ} 00^{\prime} \mathrm{W}(\times 16)$.

F. A very large specimen of Diphyes dispar Chamisso \& Eyssenhardt, 1821 (polygastric phase) from $38^{\circ} 58^{\prime} \mathrm{N}$, $22^{\circ} 37^{\prime} \mathrm{W}(\times 1.3)$.

G. Apolemia uvaria (Lesueur, 1811), three nectophores from $49^{\circ} 00^{\prime} \mathrm{N}, 11^{\circ} 27^{\prime} \mathrm{W}(\times 1.5)$.

(Photographs made by Mr. L. A. van der Laan). 


\section{Errata}

Bijdragen tot de Dierkunde vol. 43 no. 1 (1973)

R. W. M. van Soest, Planktonic coelenterates collected in the North Atlantic Ocean, page 123, table III, HYDROMEDUSAE

5th line - for Aeginura grimaldi read: Tiaranna rotunda

6th line - for Tiaranna rotunda read: Halicreas minimum. 